\title{
Clearance potential of jellyfish Aurelia aurita, and predation impact on zooplankton in a shallow cove
}

\author{
Niels Jørn Olesen* \\ National Environmental Research Institute, Vejlsøvej 25, PO Box 314, DK-8600 Silkeborg, Denmark
}

\begin{abstract}
The potential predation impact of jellyfish Aurelia aurita on zooplankton in a shallow cove was investigated. Population clearance potential was calculated from laboratory clearance rates and from measurements of medusae size and abundance during 1991 and 1992 in the shallow cove Kertinge Nor, Denmark. Clearance by $A$. aurita as a function of medusae size and water temperature was measured in the laboratory using copepods (Acartia tonsa) and rotifers (Brachionus plicatilis) as prey. Clearance rate increased (from 0.01 to $2.31 \mathrm{~h}^{-1}$ ind.-1) with increasing medusae diameter (from 4 to $44 \mathrm{~mm}$ ) when rotifers were used as prey. For medusae $>5 \mathrm{~mm}$, clearance on copepods and rotifers was similar. Water temperature had marked effect on clearance, which increased from $0.16 \mathrm{l} \mathrm{h}^{-1}$ ind $^{-1}$ at $5^{\circ} \mathrm{C}$ to $0.58 \mathrm{~h}^{-1}$ ind ${ }^{-1}$ at 14 for a $20 \mathrm{~mm}$ medusa feeding on $A$. tonsa. Between 14 and $21^{\circ} \mathrm{C}$ clearance was constant, and at $30^{\circ} \mathrm{C}$ the medusae died. In spring, when medusa were small, the population in Kertinge Nor could potentially have cleared the volume of water in the cove less than 0.1 times each day. This value was 3.5 times each day in late summer when biomass was high. Blooms of rotifers were observed in Kertinge Nor, but only during periods of low population clearance potential of $A$. aurita, and the abundance of holozooplankton in general was extremely low in Kertinge Nor during 1991 and 1992. High predation pressure by medusae appears to control zooplankton in the shallow cove, at least during summer and early fall, and $A$. aurita may thus be considered as a keystone species in the control of the trophic structure in Kertinge Nor
\end{abstract}

KEY WORDS: Scyphomedusa $\cdot$ Aurelia aurita $\cdot$ Clearance potential $\cdot$ Zooplankton control

\section{INTRODUCTION}

Although scyphomedusa are conspicuous predators on marine zooplankton communities, very few studies have quantified their impact on prey populations. Purcell (1992) found that Chrysaora quinquecirrha may control copepods in subestuaries of Chesapeake Bay, USA, but not in the main bay. Fancett \& Jenkins (1988) found that in Port Philip Bay, Australia, Cyanea capillata removed up to $20 \%$ and Pseudorhiza haeckeli removed up to $18 \%$ of fish eggs and yolk-sac larvae over the duration of these stages.

Mass occurrence of another species, Aurelia aurita, has been reported from many parts of the world including Cuba (Krumbach 1925), Japan (Yasuda 1968), Sweden (Hernroth \& Groendal 1983) and Greece (Papathanassiou et al. 1987). A. aurita has a worldwide

\footnotetext{
•E-mail: fvnjo@wpgate.dmu.dk
}

distribution (Kramp 1961), and a few sources suggest that medusae, when abundant, may deplete zooplankton stocks due to intense predation (Möller 1980, Papathanassiou et al. 1987, Schneider 1989). This may lead to secondary effects such as that described by Lindahl \& Hernroth (1983) in which blooms of dinoflagellates in Gulmar Fjord, Sweden, were caused by reduced copepod grazing due to intense predation by A. aurita on the copepods.

Except for the work of Lindahl \& Hernroth (1983), such cascading effects or top-down effects have not previously been described for any scyphomedusan species. In contrast, the influence of fish predation on zooplankton and in turn phytoplankton communities in aquatic systems is well documented (see e.g. Hrbàĉek et al. 1961, Hrbàcek 1962, Levitan et al. 1985 , Mills in Kerfoot \& Sih 1987). If the biological structure of a complex system is greatly modified by the activity of a single predatory species high in the food web, this 
individual population can be termed 'the keystone of the community structure' (Paine 1969). In the present study I evaluate the impact of predation by Aurelia aurita on zooplankton in a shallow cove and discuss the significance of $A$. aurita as a keystone species in the control of the trophic structure in this area.

Until now, studies on zooplankton control by Aurelia aurita have been done by calculating food demands of the jellyfish based on the carbon budget approach (Schneider 1989) or by measurements of the population dynamics of predator and prey in situ (Möller 1980, Papathanassiou et al. 1987). In the present study, I calculated the population clearance potential of $A$. aurita in the shallow Danish cove, Kertinge Nor, during mass occurrence of jellyfish in 1991 and 1992. This was done by combining laboratory measurements of clearance of selected zooplankton organisms with field observations of medusae size and densities. The calculated population clearance potential was then related to measurements of zooplankton biomass and densities in Kertinge Nor to determine the potential predation impact of medusae on zooplankton populations.

\section{MATERIALS AND METHODS}

Study area and sampling. All sampling of the jellyfish Aurelia aurita was conducted in Kertinge Nor, a shallow cove located on the east coast of the island of Fyn, Denmark. Kertinge Nor covers an area of $5.8 \mathrm{~km}^{2}$ and has an average depth of $2 \mathrm{~m}$ and a maximum depth of $3 \mathrm{~m}$. Further details of the cove are given in Olesen et al. (1994). Medusae for experimental purposes were sampled with a dip net and transported to the laboratory where they were used in experiments 2 to 6 h after collection. Data on water temperature, average medusae density and diameter in Kertinge Nor during 1991 and 1992 are in Olesen et al. (1994).

Clearance experiments. In laboratory experiments, clearance was measured as a function of medusae size and water temperature. The copepod Acartia tonsa (total length $1500 \mu \mathrm{m}$ ) and the rotifer Brachionus plicatilis (total length $200 \mu \mathrm{m}$ ) were chosen as prey in the present work, because copepods are believed to be the main diet of Aurelia aurita (Kerstan 1977, Möller 1978/1979), and predation by $A$. aurita on rotifers has also been demonstrated by Stoecker et al. (1987) and Båmstedt (1990). Clearance was determined by measuring the volume of water cleared of rotifers or adult copepods per unit time. Rotifers and copepods were cultured in the laboratory. Medusae were incubated in 1.2 I glass bottles with filtered $(20 \mu \mathrm{m})$ seawater from the sampling site ( 15 to $18 \% \mathrm{~S}$ ) and a known number of prey organisms. Copepods were counted individually into the containers. Rotifers were added from a stock solution and the density of this solution was determined by subsampling. The bottles were rotated endover-end (1 rpm) in dim light. Twelve bottles were employed in each experiment, and the exponential decrease in prey organisms as a function of time was followed by processing 2 or 3 bottles at appropriate intervals. The water was filtered through a $20 \mu \mathrm{m}$ plankton gauze, and the retained prey organisms were preserved in Lugol and later counted by using a dissecting microscope. Three of the 12 bottles served as controls (without medusae), and the number of prey organisms in these bottles was always unchanged by the end of each experiment. A regression analysis was performed on the data and clearance $\left(C, \mathrm{ml} \mathrm{h}^{-1}\right.$ ind $\left.^{-1}\right)$ was calculated from the equation:

$$
C=[V /(\mathrm{n} \times t)] \ln \left(C_{0} / C_{l}\right)
$$

where $V=$ volume of experimental bottle $(\mathrm{ml}), \mathrm{n}=$ number of medusae, $C_{0}$ and $C_{t}=$ number of prey organisms at time 0 and $t$, respectively, and $t=$ incubation time (h).

Two series of experiments were carried out in order to evaluate the relationship between medusae size and clearance. Details of the specific conditions for each experiment are summarized in Table 1. In the first series, Brachionus plicatilis $\left(4000 \mathrm{I}^{-1}\right)$ was used as the prey organism in 4 separate experiments with medusae of 4, 16, 30 and $44 \mathrm{~mm}$ in umbrella diameter. In the second series, Acartia tonsa $\left(83 \mathrm{l}^{-1}\right)$ was used in 6 experiments with medusa of 3,4,11,22, 30 and $47 \mathrm{~mm}$ diameter. The number of medusae added to each bottle varied from 1 to 30 depending on the average size of the medusae in the experiment (Table 1). All incubations were done at $15^{\circ} \mathrm{C}$. If temperature at the collection site was different from $15^{\circ} \mathrm{C}$, medusae were adapted to the new temperature over a $3 \mathrm{~h}$ period prior to experiment. At the end of each experiment, medusae were placed with the dorsal side down to flatten the umbrella, and the interradial diameter was measured. Incubation time varied between 2 and $25 \mathrm{~h}$ depending on the rate at which prey organisms were removed from the water. The density of prey organisms in our laboratory experiment ( 4000 rotifers $~^{-1}$ or 83 copepods $\mathrm{I}^{-1}$ ) is higher than the average density in natural zooplankton populations, and in order to extrapolate results obtained in the laboratory to the field it was necessary to demonstrate that medusae were not saturated at these high prey densities. Therefore, a series of experiments was performed to test if clearance was unchanged upon lowering the prey density $\left(2500,1250\right.$ and 625 rotifers $l^{-1}$ or 42 copepods $\mathrm{l}^{-1}$ ) (Table 1).

The relationship between water temperature and clearance was investigated in 4 experiments with Acartia tonsa as the prey organism and temperatures of $5,10,15$, and $20^{\circ} \mathrm{C}$ (Table 1). Medusae were adapted 
Table 1. Aurelia aurita. Experimental conditions during clearance experiments with rotifers and copepods as prey organisms in 1.21 containers

\begin{tabular}{|c|c|c|c|c|c|c|c|}
\hline \multirow[t]{2}{*}{ Prey } & \multicolumn{2}{|c|}{ Temperature $\left({ }^{\circ} \mathrm{C}\right)$} & \multirow{2}{*}{$\begin{array}{l}\text { Diameter of } \\
\text { medusae } \\
(\mathrm{mm} \pm \mathrm{SD})\end{array}$} & \multirow{2}{*}{$\begin{array}{l}\text { No. of medusae } \\
\text { per container }\end{array}$} & \multirow{2}{*}{$\begin{array}{c}\text { Prey } \\
\text { density } \\
\text { (ind } 1^{-1} \text { ) }\end{array}$} & \multirow{2}{*}{$\begin{array}{l}\text { Incubation } \\
\text { period } \\
\text { (h) }\end{array}$} & \multirow{2}{*}{$\begin{array}{l}\text { No. of containers } \\
\text { (incl. controls) }\end{array}$} \\
\hline & Lab & In situ & & & & & \\
\hline \multirow[t]{7}{*}{ Brachionus plicatilis } & 15 & 14 & $3.6 \pm 0.2$ & 30 & 4000 & 6 & 10 \\
\hline & 15 & 14 & $15.8 \pm 0.2$ & 10 & 4000 & 6 & 12 \\
\hline & 15 & 16 & $29.6 \pm 0.4$ & 3 & 4000 & 6 & 12 \\
\hline & 15 & 16 & $43.0 \pm 1.2$ & 1 & 4000 & 6 & 12 \\
\hline & 15 & - & $3.2 \pm 0.3$ & 30 & 2500 & 2 & 9 \\
\hline & 15 & - & $3.3 \pm 0.2$ & 30 & 1250 & 2 & 9 \\
\hline & 15 & - & $3.7 \pm 0.2$ & 30 & 625 & 2 & 9 \\
\hline \multirow[t]{11}{*}{ Acartia tonsa } & 15 & 12 & $3.3 \pm 0.8$ & 30 & 83 & 25 & 10 \\
\hline & 15 & 12 & $4.3 \pm 1.0$ & 30 & 83 & 10 & 9 \\
\hline & 15 & 15 & $10.8 \pm 1.9$ & 30 & 83 & 2 & 12 \\
\hline & 15 & 15 & $21.7 \pm 2.5$ & 5 & 83 & 2 & 13 \\
\hline & 15 & 15 & $30.0 \pm 2.1$ & 1 & 83 & 2 & 12 \\
\hline & 15 & 18 & $46.3 \pm 3.1$ & 1 & 83 & 2 & 12 \\
\hline & 5 & 10 & $32.0 \pm 2.7$ & 1 & 83 & 2 & 12 \\
\hline & 10 & 11 & $30.3 \pm 2.1$ & 1 & 83 & 2 & 12 \\
\hline & 15 & 10 & $30.0 \pm 2.1$ & 1 & 83 & 2 & 12 \\
\hline & 20 & 20 & $31.2 \pm 2.8$ & 1 & 83 & 2 & 12 \\
\hline & 15 & - & $23.0 \pm 2.1$ & 5 & 42 & 2 & 9 \\
\hline
\end{tabular}

to experimental temperature over a $6 \mathrm{~h}$ period prior to incubation. One medusa of approximately $30 \mathrm{~mm}$ in size was added to each bottle. The prey concentration was 83 ind. $\mathrm{l}^{-1}$ and the incubation ran for $2 \mathrm{~h}$. Clearance rate was calculated as described above. The frequency of bell contractions (beats $\mathrm{min}^{-1}$ ) for each individual was measured 3 times (for 1 min) during an incubation in order to evaluate the relationship between frequency of bell contractions and clearance.

Frequency of bell contractions. To test if the contraction rate of the medusae was affected in small containers, I measured the frequency of bell contractions in situ for a number of individual medusae, and compared the results with the frequency of bell contractions for the same individuals upon incubation in the $1.2 \mathrm{l}$ bottles used in the clearance experiments. In June 1992, bell contraction frequency was recorded in situ on 29 medusae (size range: 11 to $66 \mathrm{~mm}$ ). The number of beats during a $1 \mathrm{~min}$ period was counted for each individual. This was repeated 3 times at 5 min intervals. When measurements were completed, each medusa was brought to the laboratory in a 1 l glass bowl and immediately transferred carefully to a $1.2 \mathrm{l}$ incubation bottle (same type as used in the clearance experiments) and filled with water from the sampling site. After a $10 \mathrm{~min}$ acclimatization period, the number of beat per min of each medusa was measured again as the bottle was rotated end-over-end ( $1 \mathrm{rpm}$ ). The incubation temperature in the laboratory was the same as the in situ temperature $\left(15^{\circ} \mathrm{C}\right)$. After each incubation the bell diameter of the medusae was measured as above. As large medusae might be disturbed in small containers, medusae were divided into 3 size classes ( 10 to 30,30 to 50 and 50 to $70 \mathrm{~mm}$ ), and a paired $t$-test was performed for each class in order to test if there was any significant difference between frequency of bell contraction in incubation bottles versus in the field.

Population clearance potential. The population clearance potential (PCP) of Aurelia aurita in Kertinge Nor is defined as the number of times per day that the total population of jellyfish can clear a volume of water corresponding to the whole water column. The impact of the jellyfish predation on zooplankton was further illustrated by calculating the theoretical mean residence time $\left(t_{1 / 2}\right)$ for a rotifer. PCP and $t_{1 / 2}$ was calculated from the experimental clearance rates, and data obtained from Olesen et al. (1994) on A. aurita density, average medusae diameter, and water temperature in Kertinge Nor during 1991 and 1992. In these calculations it was assumed that feeding rates were constant day and night. Data on zooplankton biomass and density in Kertinge Nor during 1991 and 1992 was also obtained from previous work (Olesen et al. 1994).

\section{RESULTS}

\section{Clearance and medusae size}

The results of clearance experiments with different sized medusae of Aurelia aurita and rotifers as prey organisms are shown in Fig. 1A. The reduction of prey 


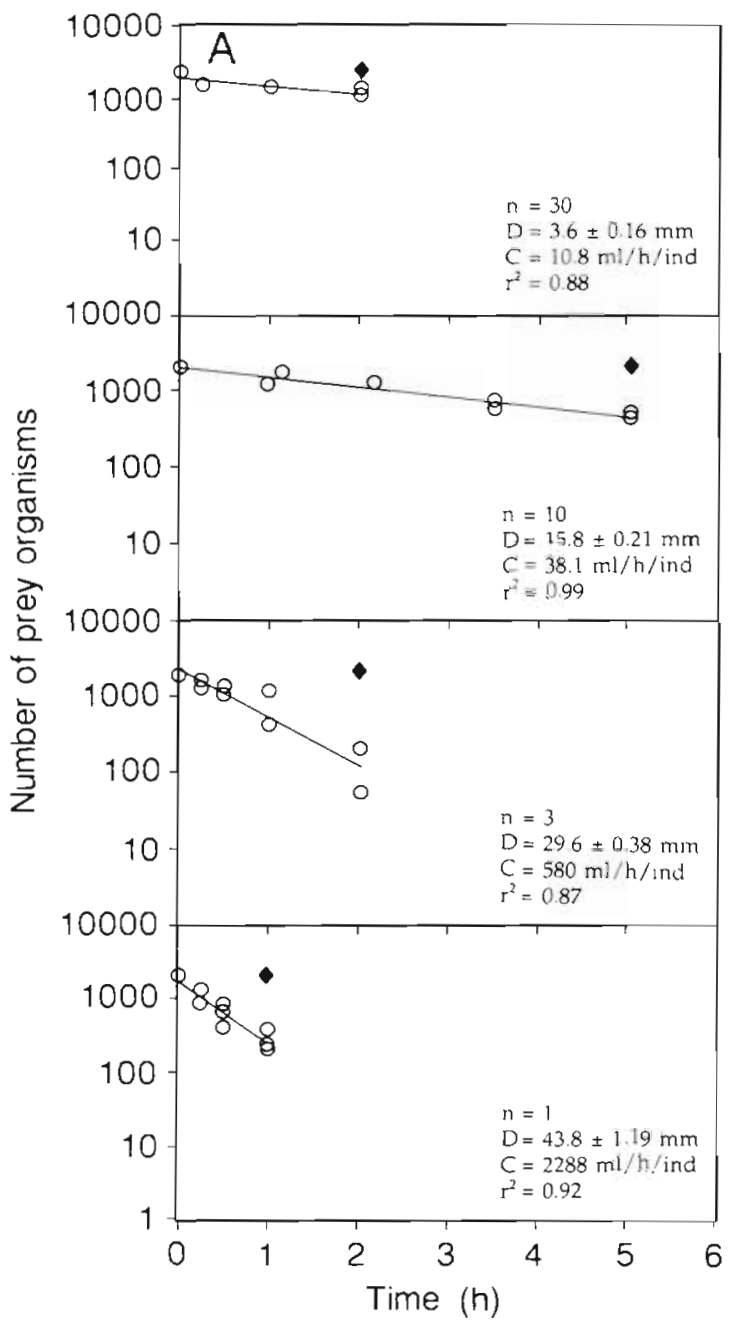

Fig. 1 Aurelia aurita. Reduction of prey as a function of time, in incubations with (A) Brachionus plicatilis and (B) Acartia tonsa as prey organisms. n: number of medusae in each experimental bottle; $D$ : medusae diameter $(\mathrm{mm})_{i} \mathrm{C}$ : clearance; $(\mathrm{O})$ experimental bottle;

(-) control bottle without medusae

organisms was always exponential, and the rate was constant throughout the incubation period with no initial lag phase. Small ephyrae with a diameter of $3.6 \mathrm{~mm}$ cleared $10.8 \mathrm{ml} \mathrm{h}^{-1}$ ind.- $^{-1}$ and clearance of a $44 \mathrm{~mm}$ medusae was $2288 \mathrm{ml} \mathrm{h}^{-1}$ ind. ${ }^{-1}$. When Acartia tonsa was used, reduction of prey was also exponential and constant with time (Fig. 1B) and clearance on rotifers and copepods was close except for the smallest

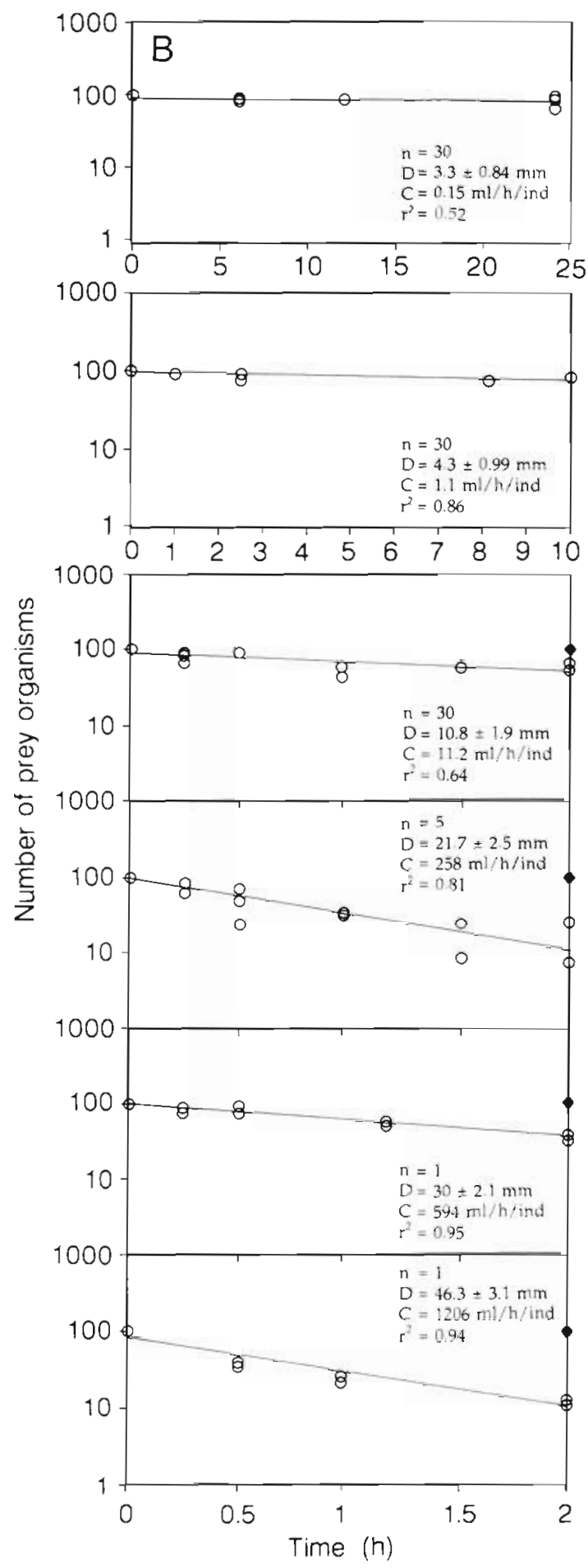

ephyrae $(<5 \mathrm{~mm})$, which cleared copepods at a very low rate. Clearance as a function of the cross sectional area of medusae is shown in Fig. 2. By linear regression it was found that clearance $\left(C, \mathrm{ml}^{-1} \mathrm{~h}^{-1}\right.$ ind.-1) increased with the cross sectional area $\left(A, \mathrm{~mm}^{2}\right)$ according to the equation:

$$
C=a(A)+b
$$




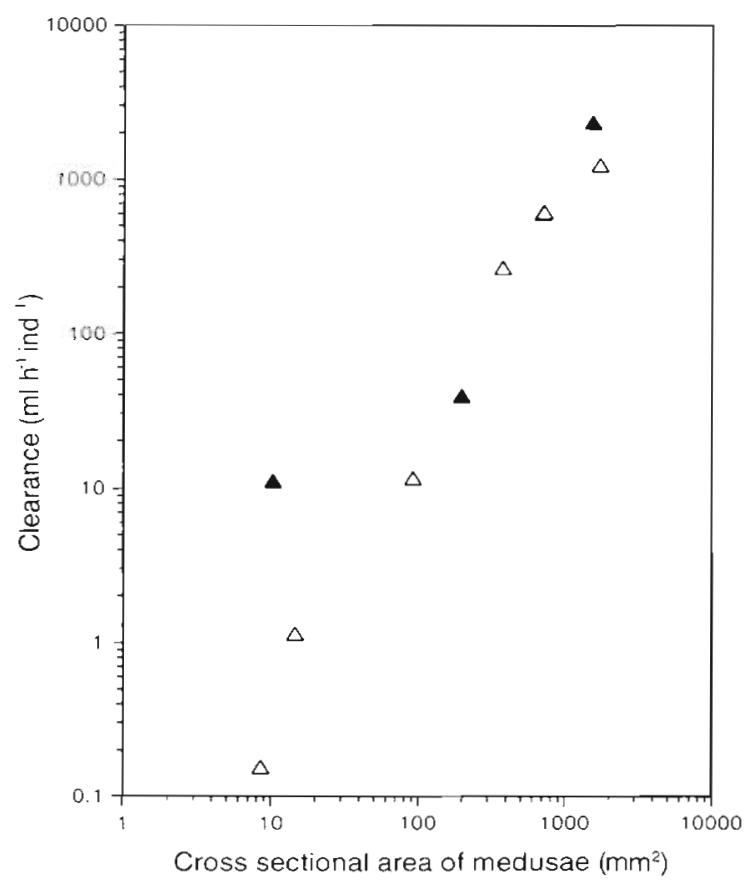

Fig. 2. Aurelia aurita. Relationship between the cross sectional area of medusa and clearance in experiment with (4) Brachionus plicatilis and ( $\Delta$ ) Acartia tonsa as prey organisms

where $a$ is the constant $1.08(\mathrm{SD}=0.18)$ and $b=-73.05$ $(\mathrm{SD}=140.3) \cdot \mathrm{R}^{2}=0.82$.

Clearance rates of medusae feeding on rotifers and copepods at different prey densities are shown in Table 2. No significant change in clearance rate was observed when densities of rotifers were lowered from 4000 to 625 ind. $1^{-1}$ or when densities of copepods were lowered from 83 to 42 ind. $1^{-1}$, and it could be concluded that medusae were not saturated at the high prey density used in the experiments (4000 rotifers $1^{-1}$ or 83 copepods $1^{-1}$ ).

\section{Clearance and temperature}

The relationship between temperature and clearance rate for a $30 \mathrm{~mm}$ medusae in experiments with Acartia tonsa as prey is shown in Fig. 3. Clearance increased from $161 \mathrm{ml} \mathrm{h}^{-1}$ ind. ${ }^{-1}$ at $5^{\circ} \mathrm{C}$ to $580 \mathrm{ml} \mathrm{h}^{-1}$ ind ${ }^{-1}$ at $14^{\circ} \mathrm{C}$. There was no further increase at $21^{\circ} \mathrm{C}$. When the temperature was raised to $30^{\circ} \mathrm{C}$, medusae died. A computer generated Boltzman fit was employed on the data obtained between 5 and $21^{\circ} \mathrm{C}$, and in this interval the relationship between clearance $\left(C, \mathrm{ml} \mathrm{h}^{-1}\right.$ ind $\left.^{-1}\right)$ and temperature $\left(t,{ }^{\circ} \mathrm{C}\right)$ could be described by the following equation:

$$
C=\left[a_{1}-a_{2} /\left(1+\mathrm{e}^{\left|t-t_{0} / d_{t}\right|}\right)\right]+a_{2}
$$

where $a_{1}=-2013.7, a_{2}=584.7, t_{0}=1.77$ and $d_{t}=1.98$. All experiments on the relationship between medusae

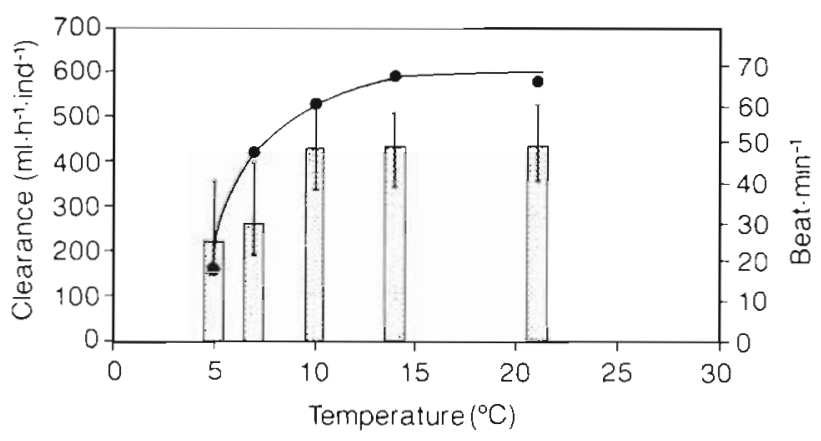

Fig. 3. Aurelia aurita. Relationship between water temperature, clearance and stroke frequency of a $30 \mathrm{~mm}$ medusae. Data points illustrate clearance; columns illustrate stroke frequency. Line is calculated from Eq. (3). SD is shown as bars

Table 2. Aurelia aurita. Clearance rates of medusae feeding on Brachionus plicatilis and Acartia tonsa at different prey densities

\begin{tabular}{|c|c|c|c|}
\hline Prey & $\begin{array}{c}\text { Diameter of } \\
\text { medusae }(\mathrm{mm})\end{array}$ & $\begin{array}{l}\text { Prey density } \\
\text { (ind. } 1^{-1} \text { ) }\end{array}$ & $\begin{array}{l}\text { Clearance } \\
\left(\mathrm{ml} \mathrm{h}^{-1} \text { ind }^{-1}\right)\end{array}$ \\
\hline $\begin{array}{l}\text { Brachionus } \\
\text { plicatilis }\end{array}$ & $\begin{array}{l}3.6 \\
3.2 \\
3.3 \\
3.7\end{array}$ & $\begin{array}{r}4000 \\
2500 \\
1250 \\
625\end{array}$ & $\begin{array}{c}10.8^{a}\left(\mathrm{r}^{2}=0.88\right) \\
9.9\left(\mathrm{r}^{2}=0.90\right) \\
9.8\left(\mathrm{r}^{2}=0.67\right) \\
7.8\left(\mathrm{r}^{2}=0.84\right)\end{array}$ \\
\hline $\begin{array}{l}\text { Acartia } \\
\text { tonsa }\end{array}$ & $\begin{array}{l}21.7 \\
23.0\end{array}$ & $\begin{array}{l}83 \\
42\end{array}$ & $\begin{array}{ll}258^{d} & \left(\mathrm{r}^{2}=0.81\right) \\
272 & \left(\mathrm{r}^{2}=0.75\right)\end{array}$ \\
\hline \multicolumn{4}{|c|}{ a Data from Fig. 1} \\
\hline
\end{tabular}

size and clearance were performed at $15^{\circ} \mathrm{C}$ but in situ temperature ranged from 5 to $22^{\circ} \mathrm{C}$. Therefore, when calculating the PCP temperature, corrections for all sizes were made to be proportional with the trend with temperature measured for $30 \mathrm{~mm}$ medusae (Fig. 3). A temperature correction factor $\left(t_{k}\right)$ was defined as:

$$
t_{k}=C_{t_{x}} / C_{t_{15}}
$$

where $C_{t_{x}}$ and $C_{t_{15}}$ are clearance $\left(C, \mathrm{ml} \mathrm{h}^{-1}\right.$ ind. $\left.^{-1}\right)$ for a $30 \mathrm{~mm}$ medusae at in situ temperature $\left(x^{\circ} \mathrm{C}\right)$ and $15^{\circ} \mathrm{C}$, respectively.

\section{Frequency of bell contractions}

The frequency of bell contractions as a function of water temperature is also shown in Fig. 3. Beat frequency increased between $5^{\circ} \mathrm{C}$ ( 24 beats $\mathrm{min}^{-1}$ ) and $10^{\circ} \mathrm{C}\left(50\right.$ beats $\left.\mathrm{min}^{-1}\right)$. The frequency of bell contractions did not increase further as temperature was raised above $10^{\circ} \mathrm{C}$.

The frequency of bell contractions at $15^{\circ} \mathrm{C}$ for 29 medusae (10 to $66 \mathrm{~mm}$ ) in situ and in 1.21 incubation bottles is shown in Fig. 4. The number of beats min $^{-1}$ 


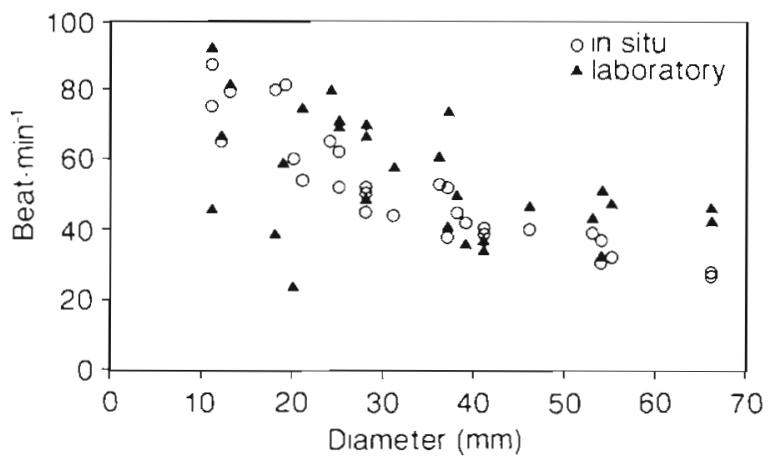

Fig 4. Aurelia aurita. Stroke frequency of umbrella in situ versus in the laboratory for different sized medusae

decreased with medusae size both in situ and in the laboratory, although this decrease seems to be less marked in the laboratory. No significant difference between frequency of bell contraction in incubation bottles versus in the field was found for medusae size 10 to 30 and 30 to $50 \mathrm{~mm}$, but medusae from 50 to $70 \mathrm{~mm}$ increased the number of beats $\mathrm{min}^{-1}$ slightly in the incubation bottles $(p<0.05)$.

\section{Population clearance potential}

The water column PCP for Aurelia aurita in Kertinge Nor during 1991 and 1992 is shown in Table 3. In 1992 PCP was low in spring but increased dramatically during summer. A maximum PCP was measured on 25 June 1992, when the population of A. aurita could clear a volume of water corresponding to the total volume of the cove 3.5 times per day. On this date, the theoretical mean residence time $\left(t_{1 / 2}\right)$ for a rotifer was less than 5 h. From June and throughout the rest of the season, clearance potential decreased. The pattern was similar in 1991 although a maximum clearance potential was reached 2 months later (in early September) than in 1992.

\section{DISCUSSION}

\section{Population clearance potential and zooplankton control}

There is evidence that Aurelia aurita, when abundant, may deplete zooplankton stocks by predation. Based on the carbon budget approach, Schneider (1989) estimated that consumption by $A$. aurita in
Kiel Bight made up between 40 and $64 \%$ of secondary production in years with high medusae standing stock, and Möller (1980) reported that increased medusae abundance was accompanied by sharp decrease in copepod standing stock. High densities of $A$. aurita were also found by Papathanassiou et al. (1987) in the Elefsis Bay (Greece), and low biomass of zooplankton was measured whenever medusae biomass was high.

Aurelia aurita probably reduces zooplankton stocks in Kertinge Nor. The density of medusae in Kertinge Nor was extremely high in 1991 and 1992, but individual growth was poor (Table 3 ) due to food limitation (Olesen et al. 1994). Maximum density in 1992 was approximately 300 ind. $\mathrm{m}^{-3}$, and numbers were in the same order of magnitude in 1991 (Table 3). The maximum mean umbrella diameter of medusae was only $54 \pm 12 \mathrm{~mm}$ and $37 \pm 15 \mathrm{~mm}$ in 1991 and 1992, respectively. The theoretically calculated PCP for A. aurita in

Table 3. Aurelia aurita. Population clearance potential $\left(\mathrm{d}^{-1}\right)$ in Kertinge Nor during 1991 and 1992. Data on medusae density and diameter obtained from Olesen et al. (1994). Clearance $\left(C, 1 \mathrm{~h}^{-1}\right.$ ind $\left.^{-1}\right)$ calculated as: $C=$ $\{[a(A)+b] / 1000\} t_{k}$ (see Eq. 2) where $A=$ cross sectional area of medusae $\left(\mathrm{mm}^{2}\right), a$ and $b=$ constants and $t_{k}=$ a temperature correction factor due to differences between temperature in the laboratory incubations and in situ (Eq. 4). Population clearance potential $\left(\mathrm{PCP}, \mathrm{d}^{-1}\right)$ calculated as: $\mathrm{C} \times \mathrm{n} \times$ $24 / 1000$ where $C=$ clearance $\left(1 \mathrm{~h}^{-1}\right.$ ind $\left.^{-1}\right)$ and $\mathrm{n}=$ medusae density $\left(\mathrm{n} \mathrm{m}^{-3}\right)$. Theoretical mean residence time of rotifers $\left(t_{1 / 2}\right)$ calculated as: $t_{1 / 2}=$ In $0.5 / \mathrm{PCB}$

\begin{tabular}{|c|c|c|c|c|c|c|}
\hline Date & $\begin{array}{l}\text { Temp. } \\
\left({ }^{\circ} \mathrm{C}\right)\end{array}$ & $\begin{array}{l}\text { Density' } \\
\text { (ind } \mathrm{m}^{-3} \text { ) }\end{array}$ & $\begin{array}{l}\text { Diameter } \\
(\mathrm{mm} \pm \mathrm{SD})\end{array}$ & $\begin{array}{c}\text { Clearance } \\
\left(\mathrm{I} \mathrm{h}^{-1} \text { ind }^{-1}\right)\end{array}$ & $\begin{array}{l}\text { PCP } \\
\left(d^{-1}\right)\end{array}$ & $\begin{array}{l}t_{1 / 2} \\
\left(\mathrm{~d}^{-1}\right)\end{array}$ \\
\hline \multicolumn{7}{|l|}{1991} \\
\hline 03 Jun & 13 & $248 \pm 292$ & $18 \pm 8.5$ & 0.20 & 1.19 & 0.58 \\
\hline 17 Jun & 15 & $231 \pm 136$ & $19 \pm 8.5$ & 0.23 & 1.28 & 0.54 \\
\hline $01 \mathrm{Jul}$ & 15 & $107 \pm 127$ & $20 \pm 8.8$ & 0.26 & 0.67 & 1.04 \\
\hline $15 \mathrm{Jul}$ & 19 & $81 \pm 73$ & $22 \pm 9.4$ & 0.36 & 0.70 & 0.99 \\
\hline $29 \mathrm{Jul}$ & 22 & $55 \pm 19$ & $27 \pm 10.8$ & 0.56 & 0.74 & 0.94 \\
\hline 22 Aug & 18 & $38 \pm 27$ & $50 \pm 13.8$ & 2.05 & 1.87 & 0.37 \\
\hline 02 Sep & 19 & $45 \pm 26$ & $54 \pm 12.0$ & 2.40 & 2.59 & 0.27 \\
\hline $19 \mathrm{Sep}$ & 15 & $29 \pm 17$ & $46 \pm 10.4$ & 1.69 & 1.18 & 0.59 \\
\hline 08 Oct & 13 & $19 \pm 16$ & $38 \pm 9.2$ & 1.14 & 0.52 & 1.33 \\
\hline 22 Oct & 8 & $10 \pm 12$ & $34 \pm 8.5$ & 0.74 & 0.18 & 3.90 \\
\hline 27 Nov & 5 & $2 \pm 1$ & $31 \pm 7.1$ & 0.20 & 0.01 & $>72.20$ \\
\hline \multicolumn{7}{|l|}{1992} \\
\hline $13 \mathrm{Feb}$ & 5 & $1 \pm 3$ & $3 \pm 1.4$ & $\sim 0$ & - & - \\
\hline $24 \mathrm{Feb}$ & 5 & $5 \pm 4$ & $3 \pm 1.4$ & -0 & - & - \\
\hline 11 Mar & 6 & $79 \pm 27$ & $3 \pm 0.9$ & $\sim 0$ & - & - \\
\hline 26 Mar & 6 & $169 \pm 104$ & $3 \pm 1.5$ & $\sim 0$ & - & - \\
\hline $10 \mathrm{Apr}$ & 9 & $186 \pm 87$ & $5 \pm 1.5$ & $\sim 0$ & - & - \\
\hline $23 \mathrm{Apr}$ & 7 & $304 \pm 129$ & $9 \pm 4.6$ & $\sim 0$ & - & - \\
\hline 11 May & 11 & $216 \pm 125$ & $13 \pm 7.8$ & 0.07 & 0.36 & 1.91 \\
\hline 26 May & 20 & $245 \pm 251$ & $15 \pm 9.3$ & 0.12 & 0.71 & 0.98 \\
\hline 10 Jun & 20 & $74 \pm 37$ & $24 \pm 14.7$ & 0.42 & 0.75 & 0.93 \\
\hline 25 Jun & 21 & $134 \pm 110$ & $37 \pm 14.7$ & 1.09 & 3.51 & 0.20 \\
\hline $19 \mathrm{Jul}$ & 18 & $41 \pm 21$ & $35 \pm 13.5$ & 0.97 & 0.95 & 0.73 \\
\hline $20 \mathrm{Aug}$ & 20 & $39 \pm 22$ & $32 \pm 10.2$ & 0.80 & 0.75 & 0.93 \\
\hline 24 Sep & 15 & $22 \pm 27$ & $28 \pm 6.9$ & 0.59 & 0.31 & 2.23 \\
\hline
\end{tabular}


Kertinge Nor varied during the seasons, as a result of variation in population density, medusae size and water temperature. Thus, PCP was high in Kertinge Nor during summer and early fall when a high number of relatively large medusae was present, and water temperature was high (Table 3 ). A. aurita could clear a volume of water corresponding to the total volume of the cove more than once per day in June and from August to September 1991 and in late June 1992. In these periods the mean residence time of rotifer or copepod was less than $15 \mathrm{~h}$ (Table 3). This suggests that $A$. aurita can influence zooplankton populations in Kertinge Nor strongly during the summer and early fall. In a laboratory experiment Berggreen et al. (1988) demonstrated that Acartia tonsa needed an algal concentration of $400 \mathrm{\mu g} \mathrm{Cl}^{-1}$ (Rhodomonas baltica) in order to reach maximal developmental rate. The mean phytoplankton biomass in Kertinge Nor during summer 1992 was well above this level (blue-green algae not included) (Larsen et al. 1994), and therefore it seems unlikely that the low number of $A$. tonsa (Table 3) was due to starvation. Peaks in zooplankton biomass were measured in July 1991 and in March, May and early June 1992 (Fig. 5). All peaks were caused mainly by blooms of rotifers, and during the same periods population clearance capacity was relatively low (Table 3, Fig. 5). Further, a high number of rotifers was found in guts of medusae during blooms of rotifers in March and June 1992 (Olesen et al. 1994).

Clearance may differ considerably among different types of zooplankton. This may be due to differences in size, shape, chemistry, and motility of the food organisms as well as inherent behavioral preferences of the predator (Stoecker et al. 1987). Therefore, one must be careful in extrapolating results from the laboratory experiments to other prey types. However, total zooplankton biomass in Kertinge Nor was extremely low during 1991 and 1992, averaging $5 \mu \mathrm{g} \mathrm{C}{ }^{-1}$ (Fig. 5), and medusae were food-limited in the cove (Olesen et

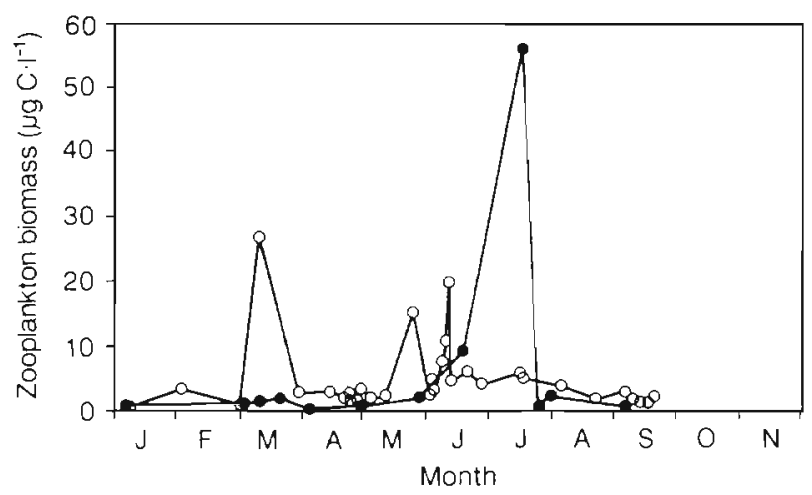

Fig. 5. Total zooplankton biomass $\left(\mu \mathrm{g} \mathrm{C}^{-1}\right)$ in Kertinge Nor during (•) 1991 and (o) 1992 (Olesen et al. 1994)
Table 4. Mean density (ind. $\mathrm{I}^{-1}$ ) of holozooplankton in Kertinge Nor during $1991(\mathrm{n}=12)$ and $1992(\mathrm{n}=32)$. Values in parentheses are the maximal observed density on any sampling date. Data obtained from Olesen et al. (1994)

\begin{tabular}{|lccccc|}
\hline & \multicolumn{2}{c}{1991} & \multicolumn{2}{c|}{1992} \\
& Stn 1 & Stn 2 & Stn 1 & Stn 2 \\
\hline Rotatoria & $2(12)$ & $1222(19263)$ & $336(10.000)$ & $2(21)$ \\
Cyclopoida & $<1(1)$ & $1(4)$ & $1(3)$ & $1(6)$ \\
Calanoida & $<1(<1)$ & $<1(1)$ & $<1(2)$ & $<1(2)$ \\
Cladocera & $<1(<1)$ & $<1(<1)$ & $<1(2)$ & $<1(4)$ \\
\hline
\end{tabular}

al. 1994), suggesting that zooplankton organisms other than rotifers and copepods might also be controlled by Aurelia aurita in Kertinge Nor. This conclusion is further supported by the fact that holozooplanktonic organisms in general were almost absent in Kertinge Nor during 1991 and 1992 (Table 4). Cyclopoid and calanoid copepods as well as Cladocera showed extremely low densities, averaging less than 1 ind. $1^{-1}$, and these organisms may be heavily preyed upon by A. aurita. Rotifers were the most abundant holozooplankton group in Kertinge Nor during 1991 and 1992, and high growth rate might explain their relatively high abundance despite intense predation by $A$. aurita. Johansson (1983) estimated that Synchaeta sp. accounted for 15 to $36 \%$ of the total annual zooplankton production in a Swedish cove, and Allan et al. (1976) speculated that rotifer production might exceed copepod production by an order of magnitude in the Rhode River, USA. The second most abundant zooplankton group in 1991 and 1992 was epibenthic copepods (Harpacticoida) (Olesen et al. 1994) which spend part of the time attached to vegetation and may therefore only be susceptible to predation by $A$. aurita during their night-time migration into the water column. It seems, therefore, that only fast growing forms (i.e. rotifers) or non-holozooplanktonic forms (i.e. harpacticoids) can sustain a relatively high abundance in Kertinge Nor, whereas other zooplankton groups are controlled by high predation pressure from the numerous medusae of $A$. aurita. There is evidence that the control of zooplankton by $A$. aurita can affect other trophic levels in Kertinge Nor. In June 1992, a high.flux of nutrient from the sediment in Kertinge Nor caused a phytoplankton bloom. As zooplankton was controlled by $A$. aurita this bloom could persist to the end of October and from June to October chlorophyll level was above $50 \mu \mathrm{g} \mathrm{Cl}^{-1}$ (Larsen et al 1994).

\section{Rates}

It is difficult to compare clearance rates from the present work with other similar studies, because experi- 
Table 5. Clearance rates $\left(\mathrm{ml} \mathrm{h} \mathrm{h}^{-1}\right.$ ind $\left.^{-1}\right)$ of prey by scyphomedusae. Medusae diameters are given in parentheses

\begin{tabular}{|c|c|c|c|c|c|}
\hline Species & Prey type & $\begin{array}{l}\text { Temp. } \\
\left({ }^{\circ} \mathrm{C}\right)\end{array}$ & $\begin{array}{l}\text { Container } \\
\text { volume }\end{array}$ & Clearance & Source \\
\hline \multicolumn{6}{|l|}{ Aurelia aurita } \\
\hline$(40-56 \mathrm{~mm})$ & $>50 \mu \mathrm{m}$ microzooplankton & 15 & 0.51 & $50-558$ & Stoecker et al. (1987) \\
\hline$(47 \mathrm{~mm})$ & Mixed zooplankton & 15 & 301 & 1395 & Båmstedt (1990) \& pers. comm. \\
\hline$(46 \mathrm{~mm})$ & Copepods & 15 & 1.21 & 1206 & This study \\
\hline$(36-88 \mathrm{~mm})$ & Fish larvae & $17-16$ & $300-64001$ & $8500-21900$ & de Lafontaine \& Leggett (1987) \\
\hline$(40 \mathrm{~mm})$ & Fish larvae & $7-8$ & $5 \mathrm{~m}^{3}$ & 55208 & Gamble \& Hay $(1989)$ \\
\hline (44 mm) & Rotifers (Brachionus) & 15 & 1.21 & 2288 & This study \\
\hline \multicolumn{6}{|c|}{ Chrysaora quinquecirrha } \\
\hline$(40 \mathrm{~mm})$ & Artemia nauplii & 26 & 201 & 10000 & Feigenbaum et al. (1982) \\
\hline$(40 \mathrm{~mm})$ & Copepods & $23-28$ & Field & 650 & Purcell $\{1992\}$ \\
\hline \multicolumn{6}{|c|}{ Pelagia noctiluca } \\
\hline$(40 \mathrm{~mm})$ & Artemia nauplii & 21 & 251 & 6875 & Morand et al. (1987) \\
\hline \multicolumn{6}{|c|}{ Cyanea capillata } \\
\hline$(40 \mathrm{~mm})$ & Fish eggs & - & 251 & 5830 & Fancett \& Jenkıns (1988) \\
\hline \multicolumn{6}{|c|}{ Pseudorhiza haeckeli } \\
\hline$(40 \mathrm{~mm})$ & Fish eggs & - & $25 \mathrm{I}$ & 16666 & Fancett \& Jenkins (1988) \\
\hline \multicolumn{6}{|c|}{ Stomolophus meleagris } \\
\hline$(55 \mathrm{~mm})$ & Fish eggs & - & Field & 130000 & Larson (1991) \\
\hline (55 mm) & Copepods & - & Field & 1700 & Larson (1991) \\
\hline
\end{tabular}

mental conditions often differ. However, the estimated values in this study are in the middle range of the values obtained by other authors for Aurelia aurita and other syphomedusae feeding on different plankton organisms (Table 5). The values given in Table 5 for A. aurita, Chrysaora quinquecirrha and Stomolophus meleagnis (40 to $55 \mathrm{~mm}$ diameter) feeding on copepods are reasonably close to each other. In general, for medusae of similar size, clearance rates tend to increase with prey size, from microzooplankton to copepods to fish eggs and larvae (Table 5). Small ephyrae ( 3 to $4 \mathrm{~mm}$ diameter) showed relatively low clearance when feeding on adult copepods in this study. Although encounter rates are likely to be higher for larger or faster moving prey, such as adult copepods compared to rotifers, prey capture may be lower for copepods than for rotifers due to difference in escape responses (Bailey \& Batty 1983), and it may be particularly difficult for small ephyrae with undeveloped tentacles to capture the relatively fast moving copepods. This could explain the low clearance rates observed when small ephyrae were offered copepods.

No work had previously been done on the relationship between water temperature and clearance for Aurelia aurita. However, water temperature should be taken into account when calculating clearance potentials for natural populations of A. aurita. Clearance for a $20 \mathrm{~mm}$ medusae at $5^{\circ} \mathrm{C}$ was only $25 \%$ of the clearance rate measured at $15^{\circ} \mathrm{C}$ (Fig. 3). Part of this effect might be explained by increased stroke frequency as temperature increase (Fig. 3).

\section{Effect of container size}

The clearance rates calculated here for Aurelia aurita medusae are my best estimates; however, there are potential sources of error. I may have underestimated clearance of $A$. aurita due to the relative small container size used. Several studies have shown that the clearance rates of numerous plankton species increases with container volume (Marshall \& Orr 1955, Ankaru 1964, Ikeda 1977, Fulton 1982, Cooper \& Goldman 1982, Murtaugh 1983, Peters \& Downing 1984). Reduced clearance in small containers has also been illustrated for gelatinous zooplankton (e.g. de Lafontaine \& Leggett 1987, Purcell \& Nemazie 1992). Thus, de Lafontaine \& Leggett (1987) investigated the effect of container size on the predation rate of $A$. aurita on capelin larvae. They found that clearance rates increased with increasing size of in situ enclosures, and it has been suggested that the searching behaviour of jellyfish predators may be impaired in small containers, perhaps due to more frequent contact with the container walls (Reeve 1980, Purcell \& Kremer 
1983). I observed that contact with the container walls was more often made by large medusae than by small medusae in 1.21 bottles and that the stroke frequency of medusae was elevated for a short period upon contact with the walls. Thus, frequency of bell contractions for medusae in the present study was increased in the incubation bottles relative to in situ for large medusae (i.e. $>50 \mathrm{~mm}$ ) (Fig. 5). If this disturbance led to less efficient feeding, clearance may have been somewhat underestimated in the present study. Thus, due to container effects, the clearance rates in the present study must be regarded as conservative estimates, and the population clearance potentials are likely to be underestimated.

\section{CONCLUSION}

When the common jellyfish Aurelia aurita occur in high numbers, it may have significant impact on zooplankton populations. An extremely high population clearance potential and a very low zooplankton biomass suggest that this species controls holozooplankton during summer and early fall in the shallow cove, Kertinge Nor, Denmark. The control of zooplankton by A. aurita may in turn affect phytoplankton level and A. aurita must be considered as a keystone species in the control of the trophic structure in this area.

Acknowledgements. This study was partly supported by the Danish National Agency of Environmental Protection (Hav90).

\section{LITERATURE CITED}

Allan JD, Kinsey TG, James MC (1976) Abundance and production of copepods in the Rode River subestuary of Chesapeake Bay. Chesapeake Sci 17:86-92

Ankaru M (1964) Some technical problems encountered in quantitative studies of grazing and predation by marine planktonic copepods. J oceanogr Soc Japan 20:221-231

Bailey KM, Batty SR (1983) A laboratory study of predation by Aurelia aurita on larval herring (Clupea harengus): experimental observation compared with model predictions. Mar Biol 72:295-301

Båmstedt U (1990) Trophodynamics of the scyphomedusae Aurelia aurita. Predation rate in relation to abundance, size and type of prey. J Plankton Res 12:215-229

Berggreen U, Hansen B, Kiørboe T (1988) Food size spectra ingestion and growth of the copepod Acartia tonsa during development: implication for determination of copepod production. Mar Biol 99:341-352

Cooper SD, Goldman CR (1982) Environmental factors affecting predation rates of Mysis relicta. Can J Fish Aquat Sci 39:203-208

de Lafontaine Y, Leggett WC (1987) Effect of container size on estimation of mortality and predation rates in experiments with macrozooplankton and larval fish. Can J Fish Aquat Sci 44:1534-1543
Fancett MS, Jenkins GP (1988) Predatory impact of scyphomedusae on ichthyoplankton and other zooplankton in Port Philip Bay. J exp mar Biol Ecol 116:63-77

Feigenbaum DL, Knowles D, Kelly M (1982) Trophic interaction of the sea nettle, Chrysaora quinquecirrha. Tech Rept, Dept Oceanogr, Old Dominion Univ, Virginia, 82(2):1-15

Fulton RS III (1982) Predatory feeding of two marine mysids. Mar Biol 72:183-191

Gamble JC, Hay SJ (1989) Predation by syphomedusae Aurelia aurita on hearing larvae in large enclosures: effects of predator size and prey starvation. Rapp P-v Rèun Cons int Explor Mer 191:366-375

Hernroth L, Groendahl F (1983) On the biology of Aurelia aurita (L.): 1. Release and growth of Aurelia aurita (L.) ephyrae in the Gullmar Fjord, Western Sweden, 1982-1983. Ophelia 22:189-199

Hrbàcek J (1962) Species composition and the amount of zooplankton in relation to fish stock. Rozpr Cesk Akad Ved Rapa Mat Pririr Yed 72:1-116

Hrbàcek J, Dvorakova M, Koŗinek M, Prochàzkova L (1961) Demonstration of the effect of the fish stock on the species composition of zooplankton and the intensity of metabolism of the whole plankton association. Verh int Verein Limnol 14:192-195

Ikeda $T$ (1977) Feeding rates of planktonic copepods from a tropical sea. J exp mar Biol Ecol 29:263-277

Johansen S (1983) Annual dynamics and production of rotifers in an eutrophication gradient in the Baltic Sea. Hydrobiologia 104:335-340

Kerfoot CW, Sin A (1987) Predation. Direct and indirect impacts on aquatic communities. Univ Press of New England, Hanover, p 118-131

Kerstan M (1977) Untersuchung zur Nahrungsökologie von Aurelia aurita Lam. Thesis, Institut für Meereskunde an der Christian-Albrecht-Universität, Kiel

Kramp PP (1961) Synopsis of the medusae of the world. J mar biol Ass UK 40:1-469

Krumbach T (1925) Scyphozoa. Handb Zool 1:522-686

Larsen G, Jürgensen C, Christensen PB, Olesen NJ, Kjerulf J, Jensen JN, Mortensen $E_{1}$ Sortkjær $O$, Andersen $P_{\text {, }}$ Rasmussen MB (1994) Kertinge Nor/Kerteminde Fjord Status og udvikling. Report series 'Havforskning fra Miljostyrelsen', No 44. National Agency of Environmental Protection, Ministry of the Environment, Copenhagen

Larson RJ (1991) Diet prey selection and daily ratio of stomolophus meleagris, a filter-feading syphomedusa from the NE Gulf of Mexico. Estuar coast Shelf Sci 32:511-525

Levitan C, Kerfoot WC, DeMott WR (1985) Ability of Daphnia to buffer trout lakes against periodic nutrient inputs. Verh int Verein Limnol 22:3076-3082

Lindahl O, Hernroth L (1983) Phyto-zooplankton community in coastal waters of Western Sweden - an ecosystem off balance? Mar Ecol Prog Ser 10:119-126

Marshall SM, Orr P (1955) On the biology of Calanus finmarchinus. VIII. Food uptake assimilation and excretion in adult and stage V. J mar biol Ass UK 34:495-529

Möller H (1978/1979) Significance of coelenterates in relation to other plankton organisms. Meeresforsch 27:1-18

Möller H (1980) Scyphomedusae as predators and food competitors of larval fish. Meeresforsch 28:90-1000

Morand P, Carrè C, Biggs DC (1987) Feeding and metabolism of the jellyfish Pelagia noctilura (Syphomedusa, Semaeostomae). J Plankton Res 9:651-655

Murtaugh PA (1983) Mysid life history and seasonal variation in predation pressure on zooplankton. Can J Fish Aquat Sci 40:1968-1975

Olesen NJ, Frandsen K, Riisgård HU (1994) Population 
dynamics, growth and energetics of jellyfish (Aurelia aurita) in a shallow fjord. Mar Ecol Prog Ser 105:9-18

Paine RT (1969) A note on trophic complexity and community stability. Am Nat 103:91-93

Papathanassiou E, Panayotidis P, Anagnostake K (1987) Notes on the biology and ecology of the jellyfish Aurelia aurita L. in Elefis Bay (Saronikos Golf, Greece). Mar Biol 8:(1)49-58

Peters RH, Downing JA (1984) Empirical analysis of zooplankton filtering and feeding rates. Limnol Oceanogr 29 : $763-784$

Purcell J (1992) Effect of predation by the scyphomedusan. Chrysaora quinquecirrha on zooplankton populations in Chesapeake Bay, USA. Mar Ecol Prog Ser 87:65-76

Purcell JE, Kremer P (1983) Feeding and metabolism of the siphonophore Sphaeronectes gracilis. J Plankton Res 5: 95-106

This article was submitted to the editor
Purcell JE, Nemazie DA (1992) Quantıtative feeding ecology of the hydromedusae Nemopsis bachei in Chesaptake Bay. Mar Biol 11.3:305-311

Reeve MR (1980) Comparative experimental studies on the feeding of chaetonaths and ctenophores. J Plankton Res 2: 381-393

Schneider G (1989) Estimation of food demand of Aurelia aurita medusae populations in the Kiel Bight/Wostern Baltic. Ophelia 31(1):17-27

Stoecker D, Michaels AE, Davies LH (1987) Grazing by the jellyfish Aurelia aurita on microzooplankton. J Plankton Res 9:901-915

Yasuda T (1968) Ecological studies on the jellyfish Aurelia aurita in. Urazoko Bay, Fukui Prefecture - 2. Occurrence pattern of the ephyrae. Bull Jap Soc scient Fish 34: 983-987

Manuscript first received: December 29, 1993

Revised version accepted: February 21, 1995 